\title{
MEDIASI PENAL DALAM SISTEM PERADILAN PIDANA INDONESIA: PENGKAJIAN ASAS, NORMA, TEORI DAN PRAKTIK
}

\author{
Lilik Mulyadi \\ Email:
}

lilikmulyadi@yahoo.com

\begin{abstract}
This research's aim is to analyze the penal mediation role from principle, norm, theory, and practical perspective of Indonesian criminal judicial system. This research is included into sociological and normative legal research using statute approach, analytical and conceptual approach, case approach and perceptional approach. The data uses primary and secondary database through observation and interview, and then descriptively analyze in qualitative and quantitative methods. The result shows that the settlement of penal mediation still could not be facilitated in national act but it is implemented in partial cases by the discretion of law officers.
\end{abstract}

Keywords: penal mediation, the enforcement of criminal law system, Indonesia's mores institution.

\begin{abstract}
Abstrak
Penelitian ini bertujuan untuk mengetahui peran mediasi penal dalam Sistem Peradilan Pidana Indonesia dari perspektif pengkajian Asas, Norma, Teori dan Praktik. Dilihat dari jenis penelitiannya merupakan penelitian hukum sosiologis dan normatif. Pendekatannya melalui pendekatan perundangan-undangan (Statute Approach), pendekatan konseptual (Analytical and Conceptual Approach), pendekatan kasus (Case Approach), dan pendekatan presepsional (perceptional approac). Data yang digunakan primer dan sekunder. Pencarian data dengan pengamatan dan wawancara. Kemudian data dianalisis secara kualitatif dan kuantitatif, selanjutnya ditulis secara deskriptif analisis. Hasil penelitian menunjukkan bahwa mediasi penal penyelesaiannya tidak secara formil difasilitasi oleh negara melainkan melalui mekanisme lembaga adat (Peradilan Gampong, Budaya Bakar Batu, Lembaga Begundem dan awig-awig), karena selama ini mediasi penal tidak diatur pada tataran Undang-Undang melainkan dikenal secara terbatas melalui diskresi penegak hukum dan sifatnya parsial.
\end{abstract}

Kata kunci: mediasi penal, sistem penegakan hukum pidana, lembaga adat Indonesia

\section{A. Pendahuluan}

Dimensi ilmu hukum hakikatnya teramat luas. Diibaratkan sebuah "pohon", hukum adalah sebuah pohon besar dan rindang yang terdiri dari daun, akar, ranting, batang, buah yang teramat lebat. Karena begitu lebatnya hukum tersebut dapat dikaji dari perspektif asasnya, sumbernya, pembedaannya, penggolongannya dan lain sebagainya. Apabila dikaji dari perspektif penggolongannya hukum dapat diklasifikasikan berdasarkan sumbernya, bentuknya, isinya, tempat berlakunya, masa berlakunya, cara mempertahankannya, sifatnya, dan berdasarkan wujudnya (Lilik Mulyadi, 2012: 439).

Dikaji dari perspektif sejarahnya, hukum pidana yang bersifat hukum publik seperti dikenal sekarang ini telah melalui suatu perkembangan panjang. Perkembangan hukum pidana dipandang sebagai suatu tindakan merusak atau merugikan kepentingan orang lain dan disusuli suatu pembalasan. Pembalasan itu umumnya tidak hanya merupakan kewajiban seseorang yang dirugikan atau terkena tindakan melainkan 
meluas menjadi kewajiban seluruh keluarga, dan bahkan beberapa hal menjadi kewajiban masyarakat. Akan tetapi, seiring berjalannya waktu, perubahan dan dinamika masyarakat yang teramat kompleks di satu sisi, sedangkan disisi lainnya terhadap regulasi pembuatan peraturan perundang-undangan sebagai kebijakan legislasi yang bersifat parsial ternyata sifat publik hukum pidana bergeser sifatnya karena relatif juga memasuki ranah privat dengan dikenal dan dipraktekkan mediasi penal (penal mediation) sebagai sebuah bentuk penyelesaian perkara diluar pengadilan.

Dikaji dari perspektif terminologinya, mediasi penal dikenal dengan istilah mediation in criminal cases, mediation in penal matters, victim offenders mediation, offender victim arrangement (Inggris), strafbemiddeling (Belanda), der AuBergerichtliche Tatausgleich (Jerman), de mediation penale (Perancis ). Pada dasarnya, mediasi penal merupakan salah satu bentuk alternatif penyelesaian sengketa diluar pengadilan (Alternative Dispute Resolution/ADR) yang lazim diterapkan terhadap perkara perdata. Pada dimensi ini, ADR di luar pengadilan telah diatur dalam UU Nomor 30 Tahun 1999 tentang Arbitrase dan Alternatif Penyelesaian Sengketa. Dalam hubungan ini telah terdapat beberapa lembaga pendorong metode ADR, antara lain Badan Arbitrase Nasional Indonesia (BANI) yang memfokuskan pada dunia perdagangan dan ADR dalam penyelesaian sengketa jasa konstruksi (UU Nomor 18 Tahun 1999 jo UU Nomor 29 Tahun 2000 jo PP Nomor 29 Tahun 2000) dengan yurisdiksi bidang keperdataan. Begitu pula ADR dikenal juga menyangkut hak cipta dan karya intelektual, perburuhan, persaingan usaha, perlindungan konsumen, lingkungan hidup dan lain-lain.

Pada hukum positif Indonesia asasnya perkara pidana tidak dapat diselesaikan di luar pengadilan, walaupun dalam hal-hal tertentu dimungkinkan adanya penyelesaian kasus di luar pengadilan. Akan tetapi, praktik penegakan hukum di Indonesia sering juga perkara pidana diselesaikan di luar pengadilan melalui diskresi aparat penegak hukum, mekanisme perdamaian, lembaga adat dan lain sebagainya. Implikasi praktek penyelesaian perkara di luar pengadilan selama ini memang tidak ada landasan hukum formalnya, sehingga lazim juga terjadi suatu kasus secara informal telah dilakukan penyelesaian damai melalui mekanisme hukum adat, namun tetap saja diproses kepengadilan sesuai hukum positif yang berlaku. Konsekuensi makin diterapkan eksistensi mediasi penal sebagai salah satu alternatif penyelesaian perkara dibidang hukum pidana melalui restitusi dalam proses pidana menunjukkan, bahwa perbedaan antara hukum pidana dan perdata tidak begitu besar dan perbedaan itu menjadi tidak berfungsi (Barda Nawawi Arief, 2008: 4-5).

Eksistensi mediasi penal merupakan dimensi baru dikaji dari aspek teoretis dan praktik. Seiring berjalannya waktu ketika semakin hari terjadi peningkatan jumlah volume perkara diselesaikan di pengadilan, maka polarisasi dan mekanisme mediasi penal merupakan salah satu solusi menekan volume perkara, sepanjang hal tersebut sungguh-sungguh dikehendaki bersama para pihak (tersangka dan korban), serta untuk mencapai kepentingan yang lebih luas, yaitu terpeliharanya harmonisasi sosial.

Mudzakkir mengemukakan kategorisasi ruang lingkup perkara yang dapat diselesaikan melalui mediasi penal adalah sebagai berikut.

1. Pelanggaran hukum pidana tersebut termasuk kategori delik aduan, baik aduan yang bersifat absolut maupun aduan yang bersifat relatif.

2. Pelanggaran hukum pidana tersebut memiliki pidana denda sebagai ancaman pidana dan pelanggar telah membayar denda tersebut (Pasal 80 KUHP).

3. Pelanggaran hukum pidana tersebut termasuk kategori "pelanggaran", bukan "kejahatan", yang hanya diancam dengan pidana denda.

4. Pelanggaran hukum pidana tersebut termasuk tindak pidana di bidang hukum administrasi yang menempatkan sanksi pidana sebagai ultimum remedium.

5. Pelanggaran hukum pidana tersebut termasuk kategori ringan/serba ringan 
dan aparat penegak hukum menggunakan wewenangnya untuk melakukan diskresi.

6. Pelanggaran hukum pidana biasa yang dihentikan atau tidak diproses ke pengadilan (deponir) oleh Jaksa Agung sesuai dengan wewenang hukum yang dimilikinya.

7. Pelanggaran hukum pidana tersebut termasuk kategori pelanggaran hukum pidana adat yang diselesaikan melalui lembaga adat . (Mudzakkir, 2007: 4).

Selain dimensi di atas, eksistensi mediasi penal dapat dikaji dari perspektif filosofis, sosiologis, dan yuridis. Pada perspektif filosofis, mediasi penal diterapkannya asas "menang-menang" (winwin) dan bukan berakhir dengan situasi "kalah-kalah" ( lo st -lost) a ta u "menangkalah" (win-lost) sebagaimana ingin dicapai oleh peradilan dengan pencapaian keadilan formal melalui proses hukum litigatif (law enforcement process). Melalui proses mediasi penal maka diperoleh puncak keadilan tertinggi karena terjadinya kesepakatan para pihak yang terlibat dalam perkara pidana tersebut yaitu antara pihak pelaku dan korban. Pihak korban maupun pelaku diharapkan dapat mencari dan mencapai solusi serta alternatif terbaik untuk menyelesaikan perkara tersebut. Implikasi dari pencapaian ini maka pihak pelaku dan korban dapat mengajukankom pensasi yang ditawarkan, disepakati dan dirundingkan antar mereka bersama sehingga solusi yang dicapai bersifat "menang- menang" (win-win). Selain itu, melalui mediasi penal ini akan mempunyai implikasi bersifat positif ketik a secara filosofis dicapainya peradilan dilakukan secara cepat, sederhana, dan biaya ringan karena pihak yang terlibat relatif lebih sedikit dibandingkan melalui proses peradilan dengan komponen Sistem Peradilan Pidana (SPP).

Dikaji dari perpektif sosiologis maka aspek ini berorientasi pada masyarakat Indonesia ketika akar budaya masyaratkannya berorientasi pada nilai budaya kekeluargaan, mengkedepankan asas musyawarah mufakat untuk menyelesaikan suatu sengketa dalam suatu sistem sosial. Tegasnya, aspek dan dimensi tersebut diselesaikan melalui dimensi kearifan lokal hukum adat. Melalui sejarah hukum dapat diketahui bahwa hukum yang mula pertama berlaku dan merupakan pencerminan kesadaran hukum rakyat Indonesia ialah kearifan lokal hukum adat.

Kemudian dikaji dari perspektif yuridis, mediasipenal dalam dimensi hukum negara ( iu s constitutum) sejatinya memang belum banyak dikenal dan masih menyisakan kontroversi, diantara pihak-pihak yang sepakat dan tidak sepakat untuk diterapkan. Persoalan esensialnya mengarah pada pilihan pola penyelesaian sengketa pidana, terkait domain superioritas negara dan superioritas masyarakat kearifan lokal. Selain dimensi diatas, implikasi lain sebenarnya eksistensi mediasi pe- nal dapat dikatakan antara "ada" dan "tiada". Dikatakan demikian, di satu sisi oleh karena mediasi penal dalam ketentuan Undang-Undang tidak dikenal dalam SPP akan tetapi dalam tataran di bawah Undang-Undang dikenal secara terbatas melalui diskresi penegak hukum dan sifatnya parsial. Kemudian, di sisi lainnya ternyata praktik mediasi penal telah dilakukan oleh masyarakat Indonesia dan penyelesaian tersebut dilakukan di luar pengadilan seperti melalui mekanisme lembaga adat.

Dengan demikian, menjadi menarik apabila lebih lanjut dikaji dimensi, "bagaimana mediasi penal dalam sistemperadilan pidana Indonesia , khususnya dari perspektif asas, teori, norma dan praktik" sehingga diharapkan adanya pemahaman bersifat komprehensif yang berguna bagi kebijakan legislasi, kebijakan aplikatif dan kebijakan administratif dalam merumuskan formulasi norma mediasi penal masa mendatang (ius constituendum).

\section{B. Metode Penelitian}

Tulisan ini merupakan hasil penelitian hukum dogmatik (dogmatic law research) dan diperkuat dengan penelitian hukum empiris .Pendekatannya melalui pendekatan perundangan-undangan (Stat- ute Approach), pendekatan konseptual (Analytical and Conceptual Approach), pendekatan kasus (Case Approach), dan pendekatan 
presepsional (perceptional approach). Kemudian sumber data sekunder berasal dari penelitian kepustakaan (library reserach) didukung oleh data primer berupa data lapangan (field research) yang diperoleh dari pengamatan (observasi) dilapangan dan serangkaian teknik wawancara terstruktur berupa pengisian questioner terhadap 123 (seratus dua puluh tiga) responden para hakim pada Pengadilan Tinggi Palangkaraya, Mataram, Jambi dan Semarang. Data primair yang diperoleh dianalisis dan diolah secara kualitatif dan kuantitatif, selanjutnya ditulis secara deskriptif analisis.

\section{Hasil Penelitian dan Pembahasan}

\section{Eksistensi Mediasi Penal}

Eksistensi mediasi penal dapat dikaji dari perspektif filosofis, sosiologis, dan yuridis. Dikaji dari perpektif sosiologis aspek ini berorientasi pada masyarakat Indonesia yang akar budayanya berorientasi pada nilai budaya kekeluargan, mengkedepankan asas musyawarah mufakat untuk menyelesaikan suatu sengketa dalam suatu sistem sosial. Tegasnya, aspek dan dim ensi tersebut diselesaikan melalui dimensi kearifan lokal hukum adat. Melalui sejarah hukum dapat diketahui bahwa hukum yang mula pertama berlaku dan merupakan pencerminan kesadaran hukum rakyat Indonesia ialah kearifan lokal hukum adat. Aspek dan dimensi ini identik dengan theorie receptie dari Snouck Hurgronje. Untuk jangka masa yang cukup lama hukum adat sebagai suatu norma hukum, bersama-sama dengan normanorma sosial lainnya dan norma agama Hindu, memainkan peranannya berfungsi sebagai alat pengendalian sosial (H.R. Otje Salman, 2007: 21).

Konsekuensi logis sebagai alat pengendalian sosial maka kearifan lokal hukum adat lahir, tumbuh, dan berkembang dalam suatu sistem sosial yang merupakan suatu sistem interaksi, jadi suatu tindakan manusia, yang melibatkan sejumlah individu. Sistem tindakan manusia itu, sebagai suatu sistem, tersusun atas jumlah bagian, yang disebut sub- sistem, yang saling berkaitan, dan saling mendukung. Tiap bagian atau sub sistem mempunyai fungsi tertentu terhadap sistem yang meliputinya. Talcott Parsons menyebut ada 4 (empat) fungsi yang meliputi, yaitu (Doyle P. Johson, 1985: 128-144):

a. Fungsi adaptasi (Adaptation), yaitu penyesuaian diri terhadap situasi dan lingkungan. Fungsi ini menunjuk pada keharusan bagi sistem-sistem sosial untuk menghadapi lingkungannya;

b. Fungsi pencapaian tujuan (Goal attainment), yang $\mathrm{m}$ erupakan pencapaian sasaran atau tujuan . Parsons beranggapan bahwa suatu tindakan diarahkan pada tujuannya. Namun perhatian yang diutamakan disini bukanlah tujuan pribadi individu, melainkan tujuan bersama para anggota dalam suatu sistem sosial;

c. Fungsi integrasi (Integration) adalah memadukan atau mengakomodasikan pelbagai faktor yang terkait pada pencapaian tujuan. Yang terdiri atas penjaminan koordinasi yang perlu antara unitunit dari sistem sosial berkaitan dengan kontribusi tiap unit pada organisasi dan berfungsinya secara keseluruhan;

d. Fungsi pemeliharaan pola atau latensi (patterns maintence atau latency) yaitu melestarikan polapola yang sudah terbentuk berdasarkan nilai-nilai.

Kearifan lokal hukum adat sebagai suatu model sosial dari Talcott Parsons titik beratnya pada fungsi integrasi. H.R. Otje Salman lebih lanjut menyebutkan hukum diarahkan untuk mengakomodasikan keseluruhan sistem sosial kemasyarakatan. Fungsi ini meliputi sistem kaidah (sistem norma) yang bertugas untuk mengoreksi perilaku menyimpang dari kaidah-kaidah bersangkutan. Jadi kaedah-kaedah itu dalam integrasi sosial menuntut perilaku tertentu yang mewujudkan peranan-peranan tertentu. Dengan demikian, kaidah-kaidah ini merupakan kerangka orientasi perilaku manusia (anggota sistem kemasyarakatan).

Kearifan lokal hukum adat, menurut pandangan Soepomo diartikan sebagai "suatu hukum yang hidup, karena ia menjelmakan perasaan hukum yang nyata dari rakyat, serta 
hukum adat bersifat dinamis dan akan tumbuh serta berkembang sejalan dengan perkembangan masyarakatnya". Temuan Soepomo tersebut bertitik tolak dari konsepsi pemikiran Friedrich Carl von Savigny dengan madzab sejarah dan kebudayaan dari van Vollenhoven. Oleh sebab itu, hukum adat bersifat dinamis dan akan tumbuh serta berkembang sejalan dengan perkembangan masyarakatnya. Dalam bahasa Friedrich Carl von Savigny, hal tersebut disebut Volksgeist (jiwa bangsa). Volksgeist berbeda-beda menurut tempat dan zaman yang dinyatakan dalam bahasa adat-istiadat dan organisasi sosial rakyat. (L.B. Curzon, 1979: 155-156). Hampir identik dengan pendapat tersebut maka penggagas sosiologi hukum (sosiology of law) Eugene Ehrlich mengatakan bahwa, "The centre of gravity of legal development lies not ini legislation nor in juristic science, nor in judicial decision, but in society it self". Eugene Ehrlich mengganti term voksgeist Savigny dengan term yang khusus dan lebih rasional yaitu fakta-fakta hukum (Rechtstaatsachen/ fact of law) dan hukum yang hidup di dalam masyaraat (living law of the people). (Eugene Ehrlich, 1936: 21).

Dimensi kearifan lokal hukum adat yang berlandaskan alam pikiran kosmis, magis dan religius ini berkorelasi aspek sosiologis dari cara pandang dan budaya masyarakat Indonesia. Dalam praktek sosial masyarakat Indonesia, lembaga mediasi penal sudah lama dikenal dan telah menjadi tradisi antara lain pada Masyarakat Papua, Aceh, Bali, Lombok, Sumatera Barat dan hukum adat Lampung.

Selain itu, sebagai perbandingan maka mediasi penal di tingkat internasional telah lama dikenal. Dalam beberapa konferensi misalnya Konggres PBB ke-9 tahun 1995 khususnya yang berkorelasi dengan manajemen peradilan pidana (dokumen $\mathrm{A} /$ CONF 169/6) disebutkan perlunya semua negara mempertimbangkan "privatizing some law enforcement and justice functions" dan "alternative dispute resolution/ADR) berupa mediasi, konsiliasi, restitusi dan kompensasi dalam sistem peradilan pidana. Kemudian dalam Konferensi Internasional Pembaharuan Hukum Pidana (International Penal Reform Conference) tahun 1999 dikemukakan bahwa salah satu unsur kunci dari agenda baru pembaharuan hukum pidana (the key elements of a new agenda for penal reform) adalah perlunya memperkaya sistem peradilan formal dengan sistem atau mekanisme informal dengan standar-standar hak asasi manusia (the need to enrich the formal judicial system with informal, locally based, dispute resolution mechanisms which meet human rights standards) yang mengindentifikasikan sembilan strategi pengembangan dalam melakukan pembaharuan hukum pidana melalui pengembangan restorative justice, alternative dispute resolution, informal justice, alternatives to custody, alternative ways of dealing with juveniles, dealing with violent crime, reducing the prison population, the proper management of prisons dan the role of civil in penal reform. Begitu pula dalam Konggres PBB ke-10 tahun 2000 (dokumen A/CONF. 187/4/Rev.3), antara lain dikemukakan bahwa untuk memberikan perlindungan kepada korban kejahatan, hendaknya diintrodusir mekanisme mediasi dan peradilan restorative (restorative justice). Kemudian, sebagai tindak lanjut pertemuan internasional tersebut mendorong munculnya dokumen internasional yang berkorelasi dengan peradilan restoratif dan mediasi dalam perkara pidana berupa the Recommendation of the Council of Eure 1999 No. $R$ (99) 19 tentang "Mediation in Penal Mattres", berikutnya the EU Framework Decision 2001 tentang "the Stannding of Victim in Criminal Proceedings" dan The UN Principles 2002 (Resolusi Ecosoc 2002/12) tentang "Basic Principles on the Use Restorative Justice Programmes in Criminal Matters". Kemudian, mediasi penal ini juga dikenal dalam beberapa Undang-Undang pada Negara Austria, Jerman, Belgia, Perancis dan Polandia.

Dari pelbagai ketentuan dipelbagai negara dapat disebutkan mediasi penal dimungkinkan dalam perkara pidana dan diberikan kerangka hukum (mediation within the framework of criminal law). Tony Peters mengemukakan gambaran pengaturan atau "legal framework" dibeberapa negara Eropa sebagai berikut (Barda Nawawi Arief, 2008: 39).

a. Ditempatkan sebagai bagian dari UU Peradilan Anak (the Juvenile 
Justice Act), yaitu di Austria, Jerman, Finlandia, dan Polandia.

b. Ditempatkan dalam KUHAP (the Code of Criminal Procedure), yaitu di Austria, Belgia, Finlandia, Perancis, dan Polandia.

c. Ditempatkan dalam KUHP (the Criminal Code), yaiu di Finlandia, Jerman, dan Polandia.

d. Diatur tersendiri secara otonom dalam UU Mediasi (the Mediation Act), seperti di Norwegia, yang diberlakukan untuk anak- anak maupun orang dewasa.

\section{Mediasi Penal dalam Sistem Peradilan Pidana Indonesia}

Mediasi penal merupakan perkembangan baru dalam ranah hukum pidana yang membawa implikasi mulai diterapkan dimensi bersifat privat ke dalam ranah hukum publik. Hasil penelitian yang dilakukan terhadap 123 responden mendeskripsikan bahwa setuju dalam kebijakan legislasi dan aplikasi masa mendatang diformulasikan norma mediasi penal $(89,43 \%)$. Akan tetapi, terhadap dasar yuridis pengaturannya responden bersikap variatif yaitu diatur dalam KUHP (18,70\%), KUHAP (42,28\%), UU tersendiri $(11,40 \%)$, peraturan di bawah UU (4,07\%) dan Peraturan MA (9,75\%) dan dilakukan oleh Kepolisian $(41,46 \%)$, Kejaksaan (12,20\%) dan Pengadilan (40,65\%).

Pada perspektif filosofis, eksistensi mediasi penal mengandung asas diterapkannya solusi "menang-menang" (winwin) dan bukan berakhir dengan situasi "kalah-kalah" (lost-lost) atau "menangkalah" (win-lost) sebagaimana ingin dicapai oleh peradilan dengan pencapaian keadilan formal melalui proses hukum litigatif (law enforcement process). Korelasi tataran filosofis ini, penelitian terhadap para responden menyebutkan bahwa nilai-nilai yang terdapat dalam mediasi penal bersumber pada kearifan lokal hukum adat $(60,98 \%)$, restorative justice $(34,96 \%)$, sistem hukum anglo saxon $(1,62 \%)$, dan sistem eropa kontinental $(0,81 \%)$. Apabila diuraikan lebih detail, hakikat mediasi penal dikembangkan dengan bertolak dari ide dan prinsip kerja (working principles) sebagai berikut. a. Penanganan konflik (Conflict Handling/ Konflikbearbeitung): Tugas mediator adalah membuat para pihak melupakan kerangka hukum dan mendorong mereka terlibat dalam proses komunikasi. Hal ini didasarkan pada ide, bahwa kejahatan telah menimbulkan konflik interpersonal. Konflik itulah yang dituju oleh proses mediasi.

b. Berorientasi pada proses (Process Orientation; Prozessorientierung): Mediasi penal lebih berorientasi pada kualitas proses dari pada hasil, yaitu: menyadarkan pelaku tindak pidana akan kesalahannya , kebutuhankebutuhan konflik terpecahkan, ketenangan korban dari rasa takut, dan sebagainya.

c. Proses informal (Informal Proceeding-Informalitat): Mediasi penal merupakan suatu proses yang informal, tidak bersifat birokratis, menghindari prosedur hukum yang ketat.

d. Ada patisipasi aktif dan otonom pada pihak (Active and Autonmous Participation-

Parteiautonomie/Subjektivierung): Para pihak (pelaku dan korban) tidak dilihat sebagai objek dari prosedur hukum pidana, tetapi lebih sebagai subjek yang mempunyai tanggung jawab pribadi dan kemam puan untuk berbuat. Mereka diharapkan berbuat atas kehendaknya sendiri.

Kemudian terhadap mediasi penal ini dalam "Explanatory memorandum" dari rekomendasi Dewan Eropa No. R. (99) 19 tentang "Mediation in Penal Matters", dikemukakan model mediasi penal sebagai berikut.

a. Model "informal mediation" Model ini dilaksanakan oleh personil peradilan pidana (criminal justice personnel) dalam tugas normalnya, yaitu dapat dilakukan oleh Jaksa Penuntut Umum dengan mengundang para pihak untuk melakukan penyelesaian informal dengan tujuan tidak melanjutkan penuntutan apabila tercapai 
kesepakatan. Pada model ini dapat dilakukan oleh pekerja sosial atau pejabat pengawas (probation officer), oleh pejabat polisi atau Hakim.

b. Model "Traditional village or tribal moots" Menurut model ini, seluruh masyarakat bertemu untuk memecahkan konflik kejahatan diantara warganya dan terdapat pada beberapa negara yang kurang maju dan berada di wilayah pedesaan / pedalaman. Asasnya, model ini mendahulukan hukum barat dan telah memberi inspirasi bagi kebanyakan program-program mediasi modern. Program mediasi modern sering mencoba memperkenalkan berbagai keuntungan dari pertemuan suku (tribal moots) dalam bentuk yang disesuaikan dengan struktur masyarakat modern dan hak-hak individu yang diakuinya menurut hukum.

c. Model "Victim-offender mediation" Menurut model ini maka mediasi antara korban dan pelaku merupakan model yang paling sering ada dalam pikiran orang. Model ini melibatkan bebagai pihak yang bertemu dengan dihadiri oleh mediator yang ditunjuk. Banyak variasi dari model ini. Mediatornya dapat berasal dari pejabat formal, mediator independen, atau kombinasi. Mediasi ini dapat diadakan pada setiap tahapan proses, baik pada tahap kebijaksaan polisi, tahap penuntutan, tahap pemidanaan atau setelah pemidanaan. Model ini ada yang diterapkan untuk semua tipe pelaku tindak pidana, ada yang untuk tipe tindak pidana tertentu (misalnya pengutilan, perampokan dan tindak kekerasan). Ada yang terutama ditujukan pada pelaku anak, pelaku pemula, namun ada juga untuk delikdelik berat dan bahkan untuk recidivist.

d. Model " Reparation negotiation programmes" Model ini semata-mata untuk menaksir atau menilai kompensasi atau perbaikan yang harus dibayar oleh pelaku tindak pidana kepada korban, biasanya pada saat pemeriksaan di pengadilan. Program ini berhubungan dengan rekonsiliasi antara para pihak, tetapi hanya berkaitan dengan perencanaan perbaikan materiel. Dalam model ini, pelaku tidak pidana dapat dikenakan program kerja agar dapat menyimpan uang untuk membayar ganti rugi/kompensasi.

e. Model "Community panels of Courts" Model ini merupakan program untuk membelokan kasus pidana dari penuntutan atau peradilan pada prosedur masyarakat yang lebih fleksibel dan informal dan sering melibatkan unsur mediasi atau negosiasi.

f. Model "Family and community group con ferences" Model ini telah dikembangkan di Australia dan New Zealand, yang melibatkan partisipasi masyarakat dalam SPP (sistem peradilan pidana). Tidak hanya melibatkan korban dan pelaku tindak pidana, tetapi juga keluarga pelaku dan warga masyarakat lainnya, pejabat tertentu (seperti polisi dan hakim anak) dan para pendukung korban. Pelaku dan keluarganya diharapkan menghasilkan kesepakatan yang komprehensif dan memuaskan korban serta dapat membantu untuk menjaga si pelaku keluar dari kesusahan/persoalan berikutnya.

Dalam perkembangannya, penyelesaian perkara di luar pengadilan maka tidak semua perkara pidana dapat dilakukan melalui dimensi mediasi penal. T. Gayus Lumbuun menyebutkan bahwa kasus hukum yang memiliki preferensi untuk diselesaikan melalui ADR adalah sebagai berikut.

Pertama, kasus-kasus yang pelaku (atau tersangka pelaku) tidak melibatkan negara. Atau, dapat pula diprioritaskan untuk tindak pidana yang term asuk kategori delik aduan. Di samping itu ADR juga dapat diperluas mencakup tindak pidana yang korbannya adalah masyarakat atau warga negara sehingga mereka sendiri yang mengungkapkan tingkat kerugian yang dialaminya.

Kedua , tindakan pidana yang walaupun melibatkan negara (sebagai tersangka pelaku), 
tetapi memerlukan penyelesaian mengingat berdampak langsung kepada masyarakat. Misalnya, untuk tindak pidana di bidang ekonomi dimana negara mengharapkan adanya pengembalian dana negara dalam kasus-kasus korupsi (T. Gayus Lumbuun, 2007:3).

Secara parsial dan terbatas sifatnya, mediasi penal diatur dalam Surat Kapolri No Pol: B/3022/XII/2009/SDEOPS tanggal 14 Desember 2009 tentang Penanganan Kasus Melalui Alternatif Dispute Resolu- tion (ADR) serta Peraturan Kepala Kepolisian Negara Republik Indonesia Nomor 7 Tahun 2008 Tentang Pedoman Dasar Strategi dan Implementasi Pemolisian Masyarakat Dalam Penyelenggaraan Tugas Polri. Pada Surat Kapolri No Pol: B/3022/XII/2009/SDEOPS tanggal 14 Desember 2009 ditentukan beberapa langkah-langkah penanganan kasus melalui ADR yaitu:

1) Mengupayakan penanganan kasus pidana yang mempunyai kerugian materi kecil, penyelesaiannya dapat diarahkan melalui konsep ADR;

2) Penyelesaian kasus pidana dengan menggunakan ADR harus disepakati oleh pihak-pihak yang berperkara namun apabila tidak terdapat kesepakatan baru diselesaikan sesuai dengan prosedur hukum yang berlaku secara profesional dan proporsional;

3) Penyelesaian kasus pidana yang menggunakan ADR harus berprinsip pada musyawarah mufakat dan harus diketahui oleh masyarakat sekitar dengan menyertakan RT/RW setempat;

4) Penyelesaian kasus pidana dengan menggunakan ADR harus menghormati norma sosial/adat serta meenuhi azas keadilan;

5) Memberdayakan anggota Polmas dan memerankan FKPM yang ada di wilayah masing- masing untuk mampu mengindentifikasi kasuskasus pidana yang mempunyai kerugian materiil kecil dan memungkinkan untuk diselesaikan melalui konsep ADR;

6) Untuk kasus yang telah dapat diselesaikan melalui konsep ADR agar tidak lagi disentuh oleh tindakan hukum lain yang kontra produktif dengan tujuan Polmas

Kemudian dalam Pasal 14 huruf $\mathrm{f}$ Peraturan Kepala Kepolisian Negara Republik Indonesia Nomor 7 Tahun 2008 Tentang Pedoman Dasar Strategi dan Implementasi Pemolisian Masyarakat Dalam Penyelenggaraan Tugas Polri ditentukan bahwa penerapan Konsep Alternative Dispute Resolution ( pola penyelesaian masalah sosial melalui jalur alternatif yang lebih efektif berupa upaya menetralisir masalah selain melalui proses hukum atau litigasi), misalnya melalui upaya perdamaian.

Selanjutnya, pengaturan penyelesaian perkara diluar pengadilan melalui mediasi penal juga diatur dalam Inpres No.8 Tahun 2002 tentang pemberian Jaminan Kepastian Hukum kepada Debitur yang Telah Menyelesaikan Kewajibannya atau Tindakan Hukum kepada Debitur yang Tidak Menyelesaikan Kewajibannya Berdasarkan Penyelesaian Kewajiban Pemegang Saham. Inpres ini ditujukan kepada beberapa Menteri/Kepala Lembaga Pemerintahan, antara lain Menteri Kehakiman dan HAM, Jaksa Agung RI, Kepala Kepolisian RI dan Ketua Badan Penyehatan Perbankan Nasional. Pada diktum pertama angka 4 Inpres No.8 Tahun 2002 disebutkan bahwa, "dalam hal pemberian kepastian hukum sebagaimana dimaksud dalam angka 1 menyangkut pembebasan debitur dari aspek pidana yang terkait langsung dengan program Penyelesaian Kewajiban Pemegang Saham, yang masih dalam tahap penyelidikan, penyidikan dan/atau penuntutan oleh instansi penegak hukum, maka sekaligus juga dilakukan dengan proses penghentian penanganan aspek pidananya, yang pelaksanaannya tetap dilakukan sesuai dengan ketentuan peraturan peundangundangan yang berlaku”.

Pengaturan mediasi penal sebagaimana konteks di atas diatur secara parsial, terbatas dan gradasi pengaturannya diatur pada level di bawah undang-undang. Akan tetapi, dalam batas pengaturan ditingkat undang-undang, untuk perkara pidana pada asasnya tidak dapat diselesaikan di luar pengadilan, walaupun dalam hal-hal tertentu, 
dimungkinkan ada penyelesaian perkara pidana di luar pengadilan akan tetapi tidak termasuk ruang lingkup mediasi penal. Ketentuan-ketentuan tersebut dapat disebutkan sebagai berikut.

a) Dalam hal tindak pidana dilakukan berupa "pelanggaran yang hanya diancam dengan pidana denda". Ketentuan Pasal 82 KUHP menentukan kewenangan/hak menuntut tindak pidana pelanggaran itu hapus, apabila terdakwa telah membayar denda maksimum untuk pelanggaran tersebut dan biaya-biaya yang telah dikeluarkan kalau penuntutan telah dilakukan. Pada asasnya, norma ketentuan Pasal 82 KUHP ini dikenal dengan istilah "afkoop" atau "pembayaran denda damai" yang merupakan salah satu alasan penghapus penuntutan.

b) Dalam hal tindak pidana dilakukan oleh anak dibawah usia 8 (delapan) tahun. Menurut ketentuan Pasal 5 UU 3/1997 tentang Pengadilan Anak maka ditentukan batas usia anak nakal yang dapat diajukan kepengadilan sekurangkurangnya 8 (delapan) tahun dan belum mencapai 18 (delapan belas) tahun. Khusus, terhadap anak di bawah usia 8 (delapan) tahun, penyidik dapat menyerahkan kembali anak tersebut kepada orang tua, wali, atau orang tua asuhnya apabila dipandang masih dapat dibina atau diserahkan kepada Departemen Sosial apabila diandang tidak dapat lagi dibina oleh orang tua/ wali/orang tua asuh.

c) Dalam hal terjadi kasus pelanggaran Hak Asasi Manusia (HAM) sebagaimana ketentuan Pasal 1 ayat 7, Pasal 76 ayat 1, Pasal 89 ayat 4 dan Pasal 96 UU 39/1999 tentang Hak Asasi Manusia yang memberi kewenangan kepada Komnas HAM untuk melakukan mediasi dalam kasus pelanggaran HAM. Aspek ini sifatnya hanya bersifat parsial, oleh karena tidak ada ketentuan secara tegas menyatakan bahwa semua kasus pelanggaran HAM dapat dilakukan mediasi oleh Komnas HAM, karena ketentuan pasal 89 ayat (4) menentukan bahwa Komnas HAM dapat juga hanya memberi saran kepada para pihak untuk menyelesaikan sengketa melalui pengadilan, atau hanya memberi rekomendasi kepada pemerintah atau DPR untuk ditindak lanjuti penyelesaiannya. Selain itu pula, ketentuan UU 39/1999 tidak mengatur secara tegas yang menyatakan bahwa akibat adanya mediasi oleh Komnas HAM itu dapat menghapuskan penuntutan atau pemidanaan, tetapi berdasarkan Pasal 96 ayat (3) hanya ditentukan bahwa, "keputusan mediasi mengikat secara hukum dan berlaku sebagai alat bukti yang sah".

Kemudian dalam RUU KUHP sebagai ius constituendum aspek penyelesaian perkara di luar pengadilan telah diatur dalam ketentuan Pasal 145 huruf d RUU KUHP dimana gugurnya kewenangan penuntutan karena telah dilakukan penyelesaian di luar proses. Selanjutnya, dalam konteks SPP khususnya dalam sub sistemnya maka pemanfaatan ADR lebih efektif dikembangkan oleh Kepolisian ketimbang Kejaksaan ataupun Pengadilan. Aspek dan dimensi ini ditegaskan oleh Adrianus M eliala sebagai berikut (Adrianus Meliala, 2007: 8-9).

"Dalam kaitan itu, maka tak terhindarkan apabila pemanfaatan ADR dalam perspektif ini lebih dirasakan pentingnya untuk dikembangkan oleh kepolisian ketimbang kejaksaan ataupun pengadilan, mengingat peran kepolisian sebagai gerbang awal dari sistem peradilan pidana. Dapat diperkirakan bahwa suatu kasus yang telah dimulai secara ADR, katakanlah demikian, akan lebih mungkin untuk diteruskan dan berakhir dengan cara ADR pula ketim bang ADR dim unculkan ditengah (ketika perkara ditangani kejaksaan) atau diakhir proses peradilan (maksudnya diputus oleh pengadilan).

Pada dasarnya, konteks mediasi penal puncaknya diharapkan dapat menekan penumpukan perkara (congestion) di pengadilan khususnya pada tingkat Mahkamah Agung. Tegasnya, walaupun adanya pembatasan perm intaan kasasi $\mathrm{m}$ elalui regulasi berdasarkan ketentuan Pasal 45A UU 5/2004 jo UU 3/2009 akan tetapi setiap tahun terjadi penumpukan perkara. Oleh karena itu, mediasi penal dapat pula menekan penumpukan perkara pada tingkat 
yudex facti (Pengadilan Negeri/Pengadilan Tinggi).

Dalam konteks demikian, maka mediasi penal hendaknya lebih ditujukan (apabila nantinya akan dibuat dalam sebuah regulasi) terhadap perkara kecil atau ringan yang dapat berupa:

1) Pelanggaran sebagaimana diatur dalam buku ketiga KUHP

2) Tindak pidana ringan (Tipiring) yang diancam dengan pidana penjara atau kurungan paling lama 3 (tiga) bulan atau denda sebanyak-banyaknya Rp. 7.500,00 (tujuh ribu lima ratus rupiah)

3) Kejahatan ringan (lichte misdrijven) sebagaimana ketentuan yang diatur dalam KUHP berupa:

a) Pasal 302 tentang penganiayaan ringan terhadap hewan

b) Pasal 315 tentang penghinaan ringan

c) Pasal 352 tentang penganiayaan ringan terhadap manusia

d) Pasal 364 tentang pencurian ringan

e) Pasal 373 tentang penggelapan ringan

f) Pasal 379 tentang penipuan ringan

g) Pasal 482 tentang penadahan ringan

4) Kejahatan sebagaimana diatur dalam Pasal 362

5) Kejahatan sebagaimana ketentuan Pasal 359 dan Pasal 360 KUHP

6) Kejahatan yang dilakukan oleh anak sebagaimana diatur dalam UU 3/1997

7) Kejahatan sebagaimana diatur dalam UU 23/2004 tentang Penghapusan Kekerasan Dalam Rumah Tangga (KDRT)

8) Penyelesaian sengketa medis

Pararel dengan dimensi di atas, penelitian terhadap para responden menginginkan bahwa mediasi penal dilakukan terhadap pencurian ringan $(4,07 \%)$, perkara bersifat pribadi $(8,94 \%)$, perkara anak $(6,50 \%)$, kekerasan dalam rumah tangga $(7,32 \%)$ dan responden yang memilih gabungan terhadap perkara pencurian ringan, bersifat pribadi dan perkara anak relatif banyak (47,96\%). Apabila perkara tersebut di atas dilakukan melalui proses dalam sub SPP relatif akan menimbulkan gejolak karena rasa keadilan masyarakat akan terusik. Misalnya, dapat disebutkan contoh kasus Ny Minah (55) warga Desa Darma Kradenan Kecamatan Ajibarang Banyumas, Jawa tengah seorang nenek pencuri tiga biji bibit kakao diperkebunan PT Rumpun Sari Antan. Selanjutnya, kasus pencurian satu buah semangka oleh Basar dan Kholil warga Kelurahan Bujel, Kecamatan Mojoroto, Kota Kediri yang divonis oleh pengadilan dan malah menimbulkan pro dan kontra dengan dibawanya kasus pencurian tersebut ke pengadilan dan dijatuhkan pidana.

Akan tetapi, dalam konteks perbandingan mediasi penal ini dibeberapa negara, dimungkinkan dalam kasus-kasus perbankan (dikenal dengan istilah "banking mediation") yang terkait dengan masalah ATM (Automatic Teller Mechine) dan Kartu Kredit (Credit Cards). Misalnya pada Negara Malaysia dimana ruang lingkup kewenangan Banking Mediation Bureau (BMB) di Malaysia, antara lain dapat menangani sengketa bernilai RM 25,000 akibat penarikan ATM yang tidak sah (Unauthorised Automatic Teller Machine withdrawals) atau akibat penggunaan kartu kredit yang tidak sah (Unauthorised use of credit cards).

Telah dijelaskan sebagaimana konteks di atas bahwasanya dikaji dari perspektif yuridis, mediasi penal dalam dimensi hukum negara (ius constitutum) sejatinya memang belum banyak dikenal dan masih menyisakan kontroversi, diantara pihak-pihak yang sepakat dan tidak sepakat untuk diterapkan. Persoalan esensialnya mengarah pada pilihan pola penyelesaian sengketa pidana, terkait dengan domain superioritas negara dengan superioritas masyarakat kearifan lokal. Selain dimensi di atas, implikasi lain sebenarnya eksistensi mediasi penal dapat dikatakan antara "ada" dan "tiada". Dikatakan demikian, di satu sisi karena mediasi penal dalam ketentuan undang-undang tidak dikenal dalam SPP akan tetapi dalam tataran di bawah undang-undang dikenal secara terbatas melalui diskresi penegak hukum serta sifatnya parsial. Kemudian, disisi lainnya ternyata praktik mediasi penal telah dilakukan oleh masyarakat Indonesia dan penyelesaian tersebut dilakukan di luar pengadilan seperti melalui mekanisme lembaga adat.

Di Indonesia, dalam praktik mayoritas 
para hakim $(87,81 \%)$ telah mengenal eksistensi mediasi penal. Belum lama berselang praktik ini terjadi di Palangkaraya. Tamrin Amal Tomagola, seorang sosiolog ketika menjadi saksi ahli dalam suatu persidangan di Pengadilan Negeri Bandung dengan merujuk pada hasil penelitiannya menyatakan bahwa hubungan seksual sebelum menikah biasa dikalangan masyarakat Dayak. Pernyataan tersebut membuat masyarakat Dayak tersinggung, menggelar aksi damai memprotes keras pernyataan Tamrin Amal Tomagola dan melakukan pembacaan pernyataan sikap Majelis Adat Dayak Nasional (MADN) yang ditandatangani Presiden MADN karena mengganggap penyataan Tamrin melukai perasaan, harkat, dan martabat masyarakat Dayak. Pernyataan itu juga melecehkan adat istiadat suku Dayak yang mengkedepankan prinsip belom bahadat (hidup bertata krama dan beradat dalam berbagai segi kehidupan). M ADN meminta Tamrin mempertanggungjawabkan apa yang telah dilontarkan di depan hukum positif, dan tuntutan hukum adat Dayak untuk menghindari terjadinya disharmoni dan konflik harizontal yang dapat merusak kehidupan masyarakat MADN juga minta Tamrin meminta maaf kepada seluruh masyarakat Dayak secara terbuka melalui media cetak dan elektronik.

Terhadap pernyataan tersebut, maka Tamrin kemudian disidang adat di Palangkaraya. Persidangan adat tersebut dilakukan oleh MADN yang diberi nama Persidangan Dayak Maniring Tuntang Menetes Hinting Bunu yang berlangsung di Ruang Betang Tingang Ngaderang (Betang Mandala Wisata) Palangkaraya, Kalimantan Tengah antara masyarakat Dayak dengan Tamrin sebagai bentuk melindungi harkat dan martabat penegakan hukum adat Dayak terhadap delegitimasi, demoralisasi, penistaan maupun penghinaan terhadap masyarakat Dayak. Selain itu pula, asasnya pernyataan Tamrin tersebut tidak sesuai dengan pandangan masyar akat Dayak yang mengganggap hubungan seksual tanpa ikatan perkawinan sebagai hal biasa, dianggap melukai perasaan, merendahkan harkat dan martabat serta pelecehan terhadap adat istiadat suku Dayak.

Dalam sidang adat yang dipimpin oleh tujuh tokoh adat Dayak Tamrin dinyatakan bersalah dan memerintahkan Tamrin untuk mencabut pernyataannya. Terhadap hal ini Tamrin yang hadir disidang tersebut bersedia menerima dan menyanggupi semua putusan majelis sidang adat dan mencabut pernyataannya dan meminta maaf kepada seluruh masyarakat Dayak di depan sidang. Kemudian, dalam sidang adat tersebut Tamrin juga haus membayar denda acara adat senilai Rp. 77.777.777 yang akan digunakan untuk acara adat dan juga harus mencabut hasil penelitian yang menyangkut hal tersebut.

Lewat sidang adat yang disaksikan langsung oleh Presiden MADN, para tokoh adat se-Kalimantan, unsur Muspida Kalteng dan ratusan masyarakat yang menjadi saksi sidang diberi nama Persidangan Adat Dayak Maniring Tuntang Manetes Hinting Bunu antara masyarakat Dayak dan Tamrin Amal Tamagola itu secara harfiah berarti memutus dendam yang berkepan jangan dalam menuju perdamaian kearah yang lebih baik antara kedua belah pihak. Sidang itu pertama kali dilakukan dan bersifat final serta mengikat. Persidangan adat tersebut bertujuan mencapai kedamaian, rekonsiliasi, kekeluargaan, serta tetap mempertahankan harkat serta martabat suku Dayak secara keseluruhan. Tuntutan terhadap Tamrin itu berdasarkan kesepakatan Tumbang Anoi 1894.

Pada masyarakat Papua misalnya dikenal "budaya bakar batu", sebagai simbol budaya lokal, yang digunakan untuk menyelesaikan sengketa atau perkara, termasuk perkara pidana, melalui upaya damai demi terpeliharanya harm oni sosial. Dengan demikian proses pidana terhadap pelaku tindak pidana oleh aparatur negara dipandang tidak diperlukan lagi, karena justru dinilai akan merusak kembali harmoni sosial yang sudah tercapai. Selain itu, pada masyarakat Nanggroe Aceh Darussalam sebagaimana UU Nomor 11 Tahun 2006 tentang Pemerintahan Aceh diterapkan dan dikenal untuk penyelesaian perkara dilakukan terlebih dahulu melalui Peradilan Gampong atau Peradilan Damai yang berdasarkan UU 
Nomor 11 Tahun 2006 penjabarannya dibuat dalam bentuk Qanun yang berhubungan dengan hukum adat seperti Qanun Aceh Nomor 9 Tahun 2008 tentang Pembinaan Kehidupan Adat dan Adat Istiadat, Qanun Aceh Nomor 10 Tahun 2008 tentang Lembaga Adat. Kemudian selain dibuat Qanun Aceh (Qanun tingkat Propinsi) terdapat juga Qanun-Qanun tingkat Kabupaten/ Kota antara lain di dalam Qanun Kabupaten Aceh Tengah Nomor 10 Tahun 2002 tentang Hukum Adat Gayo.

Kemudian lebih lanjut Pengadilan Gampong atau Pengadilan Damai juga diimplementasikan dalam Keputusan Bersama seperti di Kabupaten Aceh Tengah adanya Keputusan Bersama antara Bupati, Ketua DPRK dan Ketua MAA Kabupaten Aceh Tengah No. 373 Tahun 2008, No 320/DPRK/2008, No.Pol B/810/2008 Res Aceh Tengah dan No.110/MAA/V/2008. Selain itu, dalam Qanun Aceh Nomor 9 Tahun 2008 tanggal 30 Desember 2008 tentang Pembinaan Kehidupan Adat dan Adat Istiadat khususnya Pasal 13 menentukan, "penyelesaian sengketa/perselisihan adat dan adat istiadat diselesaikan secara bertahap", kemudian disebutkan pula, bahwa "aparat penegak hukum memberikan kesempatan agar sengketa/perselisihan diselesaikan terlebih dahulu secara adat atau nama lain".

Begitu pula di Bali, melalui desa adat pakraman diterapkannya awig-awig sebagai salah satu manifestasi bentuk mediasi penal. Misalnya, dalam Pasal (Pawos) 66 awig-awig desa pak ram an tan ah Aron Kabupaten Ka ra $\mathrm{ng}$ as em $\mathrm{d}$ is eb ut $\mathrm{k}$ a $\mathrm{n}$ ba hwa, "yang berwenang menyelesaikan perkara di desa adalah prajuru desa sebagai hakim peradilan desa adalah kelihan banjar, kalau yang berperkara berasal dari satu banjar dan bendesa kalau yang berperkara semuanya berasal dari satu desa" (Sane wenang mawosin mekadi mutusang wicara ring desa inggih punika prajuru desa sinaggeh kerta desa; ha. Kelihanbanjar, pradene sang mewicara sane patunggalan banjar; na. Bendesa, sang mewicara sami-sami ring petunggalan desa adat).

Kem udian di Nusa Tenggara Barat (Lombok), khususnya pada masyarakat suku
Sasak dikenal cara penyelesaian masalah (perkara) melalui musyawarah (Begundem) untuk mencapai perdamaian. Dalam Kotaragama, angka 49 huruf b tentang Kebidjaksanaan atau Kedermawanan Radja, ditentukan bahwa:

"Ini tjara orang tjerdik pandai berbitjara. Dalam membitjarakan sesuatu masalah oleh diantara warga desa (Negara), djika tidak ada pendahuluan nasehat mengakibatkan tidak baik, akan tetapi bila masalah diselesaikan melalui perdamaian, kedua belah fihak akan merasakan manfaatnja. Tjara inilah jang dikehendaki/diterima baik oleh Radja karena memang tjara demikian itu mendjadi ketentuan jang dinamakan keadilan"

Berdasarkan ketentuan di atas Suku Sasak dalam menyelesaikan perselisihan pertama-tama didahului memberikan peringatan atau nasehat, dan jika peringatan tidak diindahkan maka diselesaikan melalui musyawarah untuk mencapai perdamaian. Musyawarah (Begundem) dilaksanakan oleh lembaga Adat yang disebut Krama Adat sesuai tingkat dan kompetensinya. Untuk tingkat lingkungan atau Dusun (Gubuk) dilaksanakan oleh Krama Gubuk yang berwenang menyelesaikan masalah antar warga lingkungan atau antar keluarga di lingkungan tersebut. Karma Gubuk terdiri dari Kepala Lingkungan (kelian) selaku ketua adat di lingkungan, tokoh agama (kiai gubuq) dan pemuka-pemuka masyarakat sedangkan di tingkat desa dilaksanakan oleh Krama Desa yang terdiri dari Kepala Desa selaku Kepala Adat, Juru Tulis, Penghulu Desa, Pemuka Masyarakat dan Para Kelian.

\section{Simpulan}

Mediasi penal dari perspektif pengkajian asas, norma, teori dan praktik eksistensinya antara "ada" dan "tiada". Dikatakan "ada" karena ternyata praktik mediasi penal dilakukan penegak hukum, masyarakat Indonesia dan penyelesaiannya melalui mekanisme lembaga adat (Peradilan Gampong, Budaya Bakar Batu, Lembaga Begundem dan awig- awig). Dikatakan "tiada" dikarenakan mediasi pe- nal tidak diatur pada tataran undang-undang melainkan 
dikenal secara terbatas melalui diskresi penegak hukum dan sifatnya parsial. Pada tataran di bawah undang-undang mediasi penal diatur melalui Surat Kapolri No Pol: B/3022/XII/2009/ SDEOPS tanggal 14 Desember 2009 tentang Penanganan Kasus Melalui Alternatif Dispute Reso- lution (ADR) serta Peraturan Kapolri Nomor 7 Tahun 2008 Tentang Pedom an Dasar Strategi dan Implementasi Pemolisian Masyarakat Dalam Penyelenggaraan Tugas Polri. Kemudian dalam Inpres No. 8 Tahun 2002 tentang pemberian Jaminan Kepastian Hukum kepada Debitur yang Telah Menyelesaikan Kewajibannya atau Tindakan Hukum kepada Debitur yang Tidak Menyeleaikan Kewajibannya Berdasarkan Penyelesaian Kewajiban Pemegang Saham.

\section{E. Saran}

Berdasarkan simpulan disarankan sebagai berikut.

1. Praktik mediasi penal saat ini dilakukan melalui diskresi penegak hukum sehingga masa mendatang diperlukan adanya pengaturan secara limitatif terhadap perkara-perkara yang dapat dilakukan mediasi penal sehingga tidak terjadi adanya penyalahgunaan wewenang (abuse of power) dari para pihak yang terlibat dalam Sistem Peradilan Pidana.

2. Dilakukan dan diterapkannya mediasi penal maka telah terjadi pergeseran paradigma ada sifat hukum privat kedalam ranah hukum publik. Oleh karena itu, hendaknya diperlukan alternatif paling baik terhadap tahap dan proses mediasi penal tersebut apakah dilakukan pada proses pemeriksaan yang sifatnya tertutup (Kepolisian/Kejaksaan) atau melalui proses pemeriksaan yang sifatnya terbuka (Pengadilan). 


\section{Daftar Pustaka}

Adrianus Meliala. 2007. "Penyelesaian Sengketa Alternatif: Posisi dan Potensinya di Indonesia", Makalah.

Barda Nawawi Arief. 2008. Mediasi Penal Penyelesaian Perkara Diluar Pengadilan. Semarang: Pustaka Magister.

Doyle P. Johson. 1985. Teori Sosiologi Klasik dan Modern, Jakarta: PT Gramedia. Eugene Ehrlich. 1936. Fundamental Principles of the Sociology of Law, New York.

H.R. Otje Salman. 2007. Kesadaran Hukum Masyarakat Terhadap Hukum Waris, Bandung: PT Alumni.

Lilik Mulyadi. 2012. Bunga Rampai Hukum Pidana Umum dan Khusus. Bandung: PT Alumni.

L.B. Curzon. 1979. Jurisprudence, Macdonald \& Evans Ltd, Playmouth.

Mudzakkir. 2007. "Alternative Dispute Resolution (ADR): Penyelesaian Perkara Pidana Dalam Sistem Peradilan Pidana Indonesia”. makalah workshop, Jakarta, 18 Januari 2007.

T. Gayus Lumbuun. Alternatif Dispute Resolution Di Dalam Sistem Peradilan Pidana, Makalah Workshop, Jakarta, 18 Januari 2007

\section{BIODATA PENULIS:}

\section{Dr. Lilik Mulyadi, S.H., M.H.}

Dosen Ilmu Hukum Program Strata Satu (S1), Program Magister (S2) dan Program Doktor (S3) Fakultas Hukum Universitas Jayabaya, Jakarta dan Penulis Buku Ilmu Hukum. Pendidikan: S1 Alumni Fakultas Hukum Universitas Udayana Tahun 1985; S2 Alumni Magister Ilmu Hukum Universitas Udayana Tahun 2002; S3 Alumni Program Doktor Ilmu Hukum Universitas Padjadjaran, Bandung Tahun 2007. 